
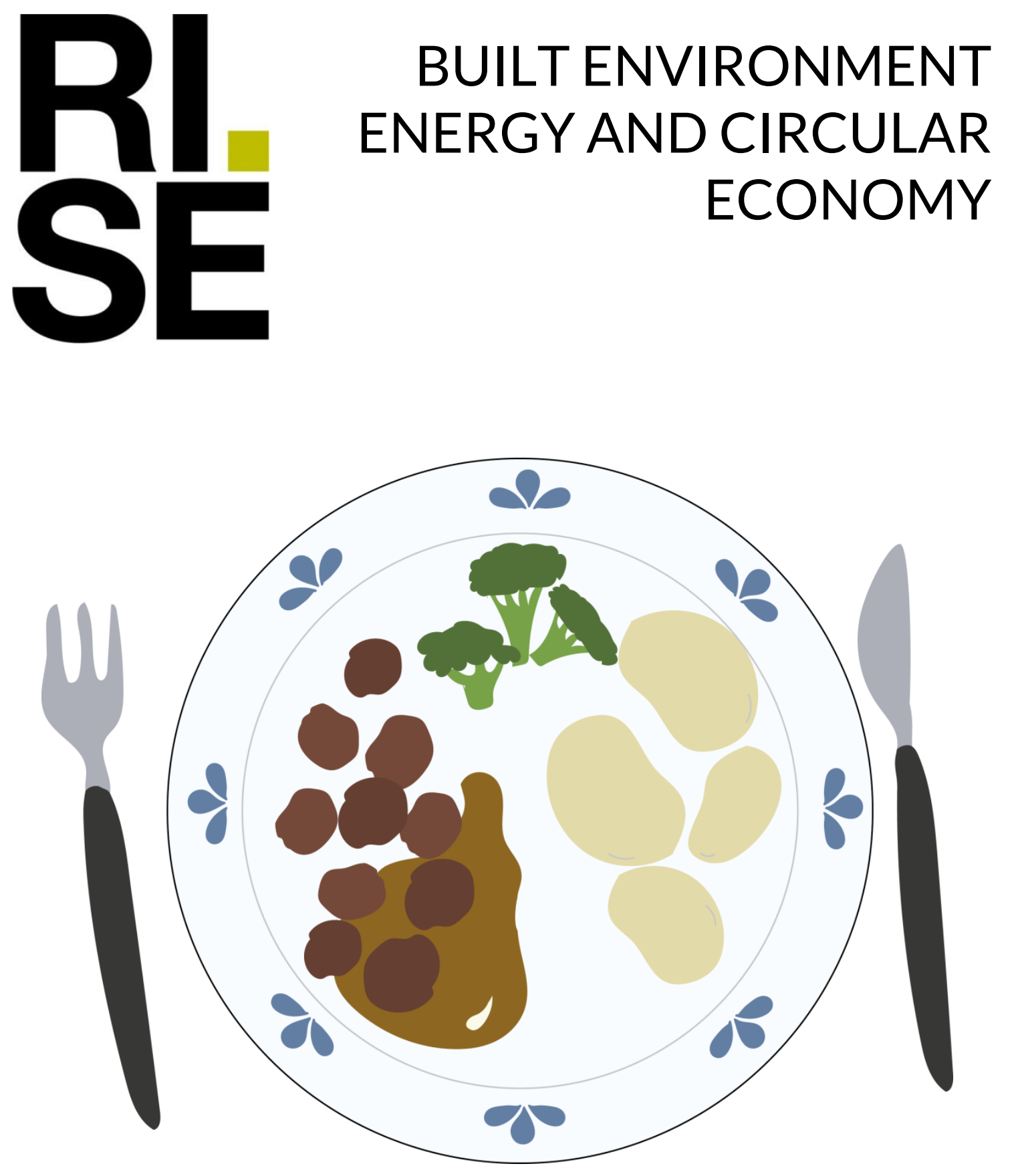

A systems perspective on chemical production from mixed food waste: The case of bio-succinate in Sweden

Emma Rex, Erica Rosander (KTH), Frida Røyne, Andres Veide (KTH) and Johanna UImanen

RISE Report 2018:30 


\section{A systems perspective on chemical production from mixed food waste: The case of bio-succinate in Sweden}

Emma Rex, Erica Rosander (KTH), Frida Røyne, Andres Veide (KTH) and Johanna Ulmanen 


\section{Abstract}

\section{A systems perspective on chemical production from mixed food waste: The case of bio-succinate in Sweden}

The option of producing the chemical succinic acid from bio-based resources is well in line with current political and industrial ambitions for a bio-based economy. A little explored but intriguing biomass feedstock opportunity is food waste. Mixed food waste is especially appealing as it represents less resource competition than more

homogenous food waste fractions. The feasibility of producing succinic acid from mixed food waste depends on both technical and societal system structures. Therefore, to assess the production prospect, it is important to investigate all relevant system components. This study explores from such multiple perspectives the feasibility of chemical production as a viable added pathway for mixed food waste, using microbial production of succinic acid from municipal solid waste in Sweden as an example. The perspectives explored are: 1) feedstock feasibility, 2) societal drivers and barriers for technology progress, and 3) resource availability. Findings show that even though, from a technical feasibility and resource availability perspective, production seems possible, it lacks institutional support and actor commitment and alignment for development in Sweden. Findings also show that a holistic and interdisciplinary systems perspective contributes valuable insight when assessing prospects for bio-based chemicals.

Key words: Succinic acid, Municipal solid waste, Bio-refinery, Systems approach, Waste management

RISE Research Institutes of Sweden AB

RISE Report 2018:30

ISBN: 978-91-88695-67-3

Göteborg 2018

Front cover picture: Louise Quistgaard 


\section{Content}

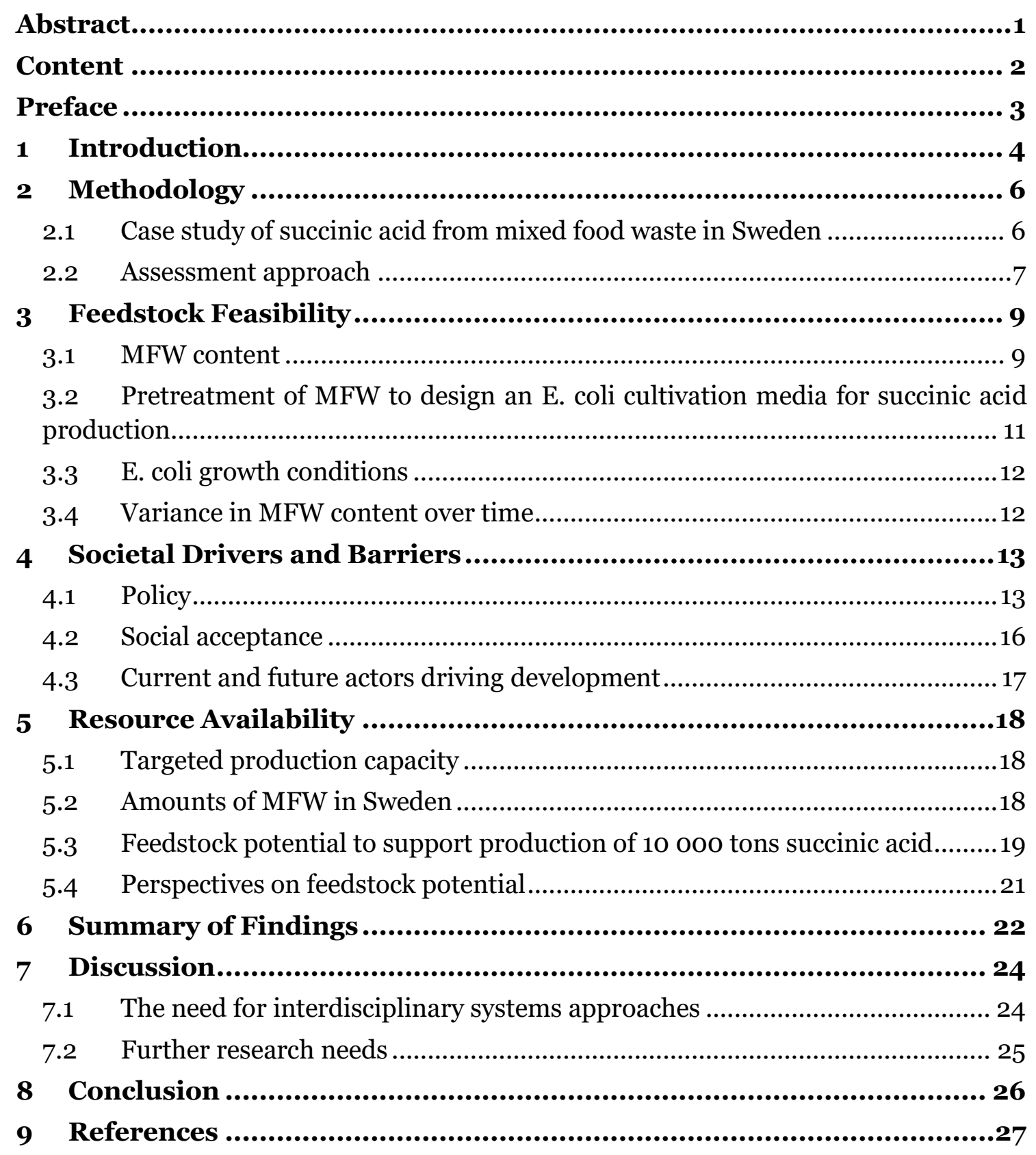




\section{Preface}

A key challenge for reducing the negative impact of climate change is the substitution of fossil resources with alternative and renewable options. The research project "Introducing high value product formation into the biorefinery" was initiated with the goal of exploring the possibility of using food waste for producing bio based chemicals. To support the technical research, systems analysis was applied to identify system potentials and weaknesses. This study is one of the results of that work.

This report is the preprint for a scientific article with the same name (https://doi.org/10.1016/j.resconrec.2017.05.012), published in the journal Resources, Conservation \& Recycling.

The Swedish Research Council Formas is gratefully acknowledged for financial support (Project no. 211-2013-70). Thanks are also due to Ragn-Sells AB for kindly providing the mixed food waste used in the study. 


\section{Introduction}

The European Commission (2016b) has identified food waste as a resource opportunity for the bio-economy; that is for the substitution of fossil with biomass resources for the sustainable production of a range of products (BECOTEPS 2011). As the use of food crops for non-food applications has been questioned, for example, due to negative effects on food security (Pimentel and Burgess 2014, To and Grafton 2015), food waste represents a promising alternative. In line with bio-economy ambitions, food waste is gaining increasing interest among researchers in chemistry and biotechnology as a feedstock for various kinds of fuels, chemicals, and materials (Lin et al. 2013, SanchezVazquez et al. 2013, Begum et al. 2016). Even though the demand for biofuel is increasing, stand-alone biofuel production is often an economic challenge, as fuel is a low-value product in economic terms (Bozell and Petersen 2010). Co-production with chemicals can generate a necessary added economic value (International Energy Agency 2013). The biotechnical feasibility of producing high-value chemicals from food waste has been demonstrated by several researchers (Sakai et al. 2004, Huang et al. 2015, Liu et al. 2016) and even on the pilot plant stage (Wageningen UR 2016).

An example of a platform chemical that can be made from food waste is succinic acid (SA) (Leung et al. 2012, Zhang et al. 2013, Sun et al. 2014). SA is a water-soluble crystal, traditionally made from fossil resources, that is used as a chemical intermediate in a high number of chemicals and products: medicine, the manufacture of lacquers, perfume, and as a sequestrant, buffer, and neutralizing agent in food (Lewis 2007). It can also be used as an intermediate for producing bio-degradable polymers (NOVA Institute 2015b). This convertibility makes SA a high-value platform chemical, and, as a result, the US Department of Energy has selected bio-based SA (i.e. SA produced from biomass) as one of the top bio-based chemicals from a market perspective (US Department of Energy 2004). Bio-based SA is already produced commercially by several companies (Choi et al. 2015), often through the biotechnological fermentation of refined sugars or starch from cultivated crops (e.g. corn).

The production of chemicals from food waste has, so far, primarily involved specified industrial waste streams from well-defined sources. Examples of applications include the production of ethanol from leftover bread (Leung et al. 2012), SA from waste coffee grounds (ACS 2012), and the conversion of citrus residues into feed, essential oils, and biofuels (Lin et al. 2013). Compared to such "pure" industrial waste streams that often have the benefit of being relatively homogenous and uncontaminated, mixed food waste is much less explored. Sanchez-Vazquez et al (2013) have concluded that it is the waste from agriculture, postharvest, processing, and distribution that is sufficiently uncontaminated that can be used in secondary processes, such as polymer production, while consumer waste generally can be assumed to be too contaminated for secondary processes other than anaerobic digestion. Yet there are many advantages if more complex waste streams are used. Biomass does not exist in absolute abundance (Scarlat et al. 2015), and, in a growing bio-economy, there are many potential applications for different biomass sources. Food waste is generated in all parts of the food value chain; from primary production through food industry, to retail and distribution, restaurants, catering, and households. The nearer the consumer, the more heterogeneous, variable, contaminated, impure, and degraded waste streams often are, however, these waste 
streams compete less with other purposes. Therefore, from a resource point of view, it is appealing to explore the opportunities of utilizing the heterogeneous food waste fractions close to the consumer: mixed food waste (MFW). If the MFW that today largely goes to composting or biogas were used for bio-based chemicals and material production, this would mean advancement to a higher level in the bio-economy's value pyramid (Betaprocess 2012, BioBased Economy n.d.).

Several different production routes for bio-based SA exist, mainly based on cultivation through the use of microbial strains (see e.g. Song and Lee 2006). The conversion of food waste to chemicals through microbial cultivation has the benefit of exploiting the inherent chemical complexity of the waste, which is lost in the conversion to biogas or if the waste is composted (Lin et al. 2013). Extensive research has been performed on developing a microbial production of bio-based SA (Ahn et al. 2016), and great technical progress on suitable micro-organisms, culture conditions, and integrated production has been made in recent decades (Cheng et al. 2012). Although mainly focused on defined nutrient media, a few examples also exist where the technical feasibility of MFW SA production has been explored and deemed to have intriguing potential (Sun et al. 2014).

In parallel to feedstock availability and feasibility, the importance of wider system challenges related to political ambitions, actors, and markets is often highlighted in relation to the realization of bio-economy and green chemistry and materials (see e.g. European Commission 2014, Swedish Energy Agency 2014, SAT-BBE 2016). For biobased SA, extensive attention has been paid to finding economically viable production routes (Cao et al. 2013, Ahn et al. 2016). However, from a sustainability transition studies perspective, actors' willingness and capacity to act and collaborate as well as policies, norms, and values in society are also critical for the success or failure of the development and market diffusion of a novel and potentially sustainable technology (Bergek et al. 2008, Grin et al. 2010, Markard et al. 2012). Yet, in waste reduction and resource management, an end-of-pipe approach focusing on treatment processes of an already existing waste still dominates, which often fails to recognize many of the challenges throughout the production and consumption system (Singh 2016).

This study reports on multiple perspectives involved in the exploration of chemical production as a viable added pathway for MFW, including both the feasibility and availability of the feedstock, and societal drivers and barriers. This was done by means of a case study of the microbial production of SA using an organic fraction of municipal solid waste in Sweden as the feedstock. Insights from the study serve as a starting point for the discussion of methods and aspects to consider when analyzing the prospects of using MFW for the production of chemicals and related materials more broadly. 


\section{Methodology}

This section introduces the case study, the systems perspectives with which the case is analyzed, and the main data sources used.

\subsection{Case study of succinic acid from mixed food waste in Sweden}

The case study involved microbial growth on MFW derived from municipal solid waste to produce bio-based SA in Sweden. This is a tentative production route in which the organic fraction of municipal solid waste is used as a nutrient source for the cultivation of bacterial strains of the species Escherichia coli to produce SA for further polymerization to various products. Municipal solid waste was received from the waste management company Ragn-Sells $\mathrm{AB}$, a full-scale facility that collects waste from the municipality of Stockholm, Sweden. The company collects non-source sorted household waste together with leftover food from grocery stores. Thus, the MFW referred to in this study is of a more complex character than the MFW mostly used in the literature (more defined waste from cafeterias, restaurants, and source-sorted households).

A production system, using an engineered E. coli strain as the host was chosen as the model process. E. coli has the advantage over other production strains in that simple and cheap feedstock can be used. Also, E. coli has a high maximum theoretical yield, determined with metabolic flux analysis, of SA ( $1.67 \mathrm{~mol} / \mathrm{mol}$ of glucose) compared to other organisms (Hong et al. 2003).

The case study was selected by participating academic and industry partners in a multidisciplinary research project exploring how MFW, combined with advanced knowledge on biotechnology, can be turned into bio-based chemical and related products with higher value than biogas and potentially complement the current biogas production process (FORMAS 211-2012-70). Bio-based SA production using modified E. coli strains was chosen for the case study, from among many potentially high-value chemical processes, due to its maturity.

A specific country was selected for the study: Sweden. Sweden represents an intriguing potential for chemical production from MFW; the country has had a landfill ban on organic waste since 2005 (European Environmental Agency 2013), and a welldeveloped infrastructure for the biological valorization of food waste. Today, most of this waste goes to anaerobic digestion to produce biogas (Avfall Sverige 2016b). Sweden also has a chemical industry with a variety of actors along the value chain (Mossberg 2013). Furthermore, Sweden has a high share of renewable energy consumption compared to other European member states (European Commission 2009). This is also true for the Swedish transport sector, whose share of renewables is dominated by biofuels (Swedish Energy Agency 2015, Eurostat 2016). Nevertheless, Swedish substitution of fossil resources with biomass in the chemicals and materials industry remains in its infancy. 
Bio-based SA is expected to substitute fossil succinate and other fossil building blocks in existing chemical conversion routes and product applications. This implies that the main changes in the value chain of SA will be in the beginning of the process. Consequently, this case study focuses on the possibility of using MFW as feedstock for SA production. It centers on feedstock availability and feasibility along with premises for market implementation. The study does not assess specific production technologies, nor does it assess economic feasibility or the possibility of co-production with other products.

\subsection{Assessment approach}

The multidisciplinary FORMAS research project referred to above involves a number of perspectives which together constitute the systems approach of this study: 1) feedstock feasibility, 2) societal drivers and barriers for technology progress, and 3) resource availability.

Feedstock feasibility was evaluated based on growth requirements for a generic E. coli cell, laboratory tests, and input from the waste industry. Ffocus was on using MFW as a feedstock for bio-based SA production, not the biotechnical conversion from nutrient media to SA. Feedstock feasibility was explored using literature studies and laboratory tests as shown in Table 1. The laboratory tests included analyses of the elementary composition and carbohydrate content of MFW. Cultivation trials using both a liquid and a solid fraction of MFW were also conducted to assess the potential of various fractions of MFW.

The societal drivers and barriers of the prospective value chain of producing SA from MFW were assessed using a transition studies perspective. More specifically, the analytical perspective of Technology Innovation Systems (TIS) was selected, which is frequently used to study barriers and drivers of potentially sustainable technology development (see for instance Hekkert et al. 2007, Bergek et al. 2008). The focus in this study is on the structural elements of the TIS approach. These are presented as three analytical categories - actors and networks, policies, and social acceptance shown in Table 1 below. Considering the prospective nature of the bio-based SA case, a prospective approach to the analysis of actors and networks (cf. Markard et al. 2009) was applied.

Resource availability is a vital aspect in any transition towards a bio-economy, where limited resources and competition among alternative uses of biomass constitute major concerns (Scarlat et al. 2015). This study accounts for resource availability by introducing an example production system and relating the need for MFW in this tentative facility to statistics on the material flows of MFW in Sweden today as well as relating to political targets for the material flows of MFW.

Data was collected for societal drivers and barriers as well as resource availability simultaneously through workshops, interviews, and literature studies (academic papers, policy papers, and reports as well as other publications from various institutes, industries, and NGOs) during 2014-2015. In all, six workshops were performed, complemented with six interviews for further clarification. Workshops and interviews included representatives from all parts of a prospective value chain for SA production from MFW, such as waste managers, biogas producers, biorefinery developers, bio 
chemical researchers, chemical product distributors and developers, and representatives from the agriculture and food industry, the chemical processing industry, , and a chemical industry association. Interviewees and workshop delegates have been anonymized and are jointly referred to as informants in the text.

Table 1 presents the different approaches chosen for the three perspectives, the questions they are intended to answer, and the main sources of data in each approach. Taken together, these perspectives give a first indication of the potential of producing chemicals from MFW.

Table 1. Perspectives, approaches, questions, and data sources addressed

\begin{tabular}{|c|c|c|c|}
\hline & Approach & Question explored & Main data sources \\
\hline \multirow{4}{*}{ 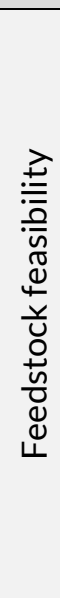 } & $\begin{array}{l}\text { Elementary analysis and } \\
\text { its change over time }\end{array}$ & $\begin{array}{l}\text { What substances/molecules } \\
\text { does MFW contain? Are they } \\
\text { suitable for E. coli growth? }\end{array}$ & $\begin{array}{l}\text { Sampling of MFW during one year. } \\
\text { Elementary analysis } 1 \text { of batch JAN- } \\
\text { 2014. Variance studies using } \\
\text { carbohydrate hydrolysis } 2 \text { on all } \\
\text { batches. Calculations based on E. } \\
\text { coli growth requirements. }\end{array}$ \\
\hline & Hydrolysis & $\begin{array}{l}\text { Can the carbon sources in } \\
\text { MFW be made more } \\
\text { accessible for E. coli uptake? }\end{array}$ & $\begin{array}{l}\text { Enzymatic hydrolysis and } \\
\text { carbohydrate analysis (Rosander et } \\
\text { al. 2016) }\end{array}$ \\
\hline & $\begin{array}{l}\text { Laboratory cultivating } \\
\text { tests }\end{array}$ & Does E. coli grow on MFW? & $\begin{array}{l}\text { Cultivation trials using various } \\
\text { cultivation techniques (Rosander et } \\
\text { al. 2016) }\end{array}$ \\
\hline & $\begin{array}{l}\text { Mechanical property } \\
\text { testing }\end{array}$ & $\begin{array}{l}\text { Is the water content in MFW } \\
\text { optimal for E. coli growth? }\end{array}$ & $\begin{array}{l}\text { Fractionation studies and moisture } \\
\text { content analysis. }\end{array}$ \\
\hline \multirow{3}{*}{ 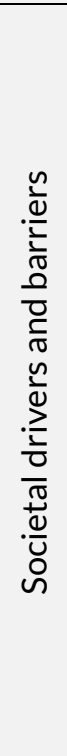 } & Policy analysis & $\begin{array}{l}\text { How do existing formal rules } \\
\text { and regulations influence the } \\
\text { availability and use of MFW } \\
\text { for SA production? }\end{array}$ & $\begin{array}{l}\text { Literature studies of a) policy } \\
\text { documents (e.g. directives and } \\
\text { goals), and b) studies of policy } \\
\text { implications (e.g. research reports), } \\
\text { complemented with workshop and } \\
\text { interview data. }\end{array}$ \\
\hline & $\begin{array}{l}\text { Analysis of societal } \\
\text { acceptance }\end{array}$ & $\begin{array}{l}\text { How do norms and values in } \\
\text { society influence the } \\
\text { prospects of using MFW for } \\
\text { SA production? }\end{array}$ & $\begin{array}{l}\text { Interviews and workshops } \\
\text { complemented with analysis of } \\
\text { discussions in related areas, such as } \\
\text { GMO and food versus fuel (e.g. } \\
\text { through newspaper articles, NGO } \\
\text { webpages, and research reports). }\end{array}$ \\
\hline & $\begin{array}{l}\text { Mapping of current and } \\
\text { future actors driving } \\
\text { development }\end{array}$ & $\begin{array}{l}\text { Can the right type of actors be } \\
\text { mobilized to realize a SA value } \\
\text { chain, from supply to demand? }\end{array}$ & $\begin{array}{l}\text { Interviews and workshops } \\
\text { dedicated to mapping key actors } \\
\text { and networks that are and may } \\
\text { contribute to the value chain. This } \\
\text { was complemented with a } \\
\text { literature review of the future }\end{array}$ \\
\hline
\end{tabular}

\footnotetext{
${ }^{1}$ Performed by Eurofins Environment Testing AB, Lidköping, Sweden (standard European methods). Thawed slurry was fractionated (centrifugation $4000 \mathrm{x}$ g, $15 \mathrm{~min}$, Beckman AVANTI) to yield a solid and a liquid fraction. The solid fraction was dried over night at approximately $95{ }^{\circ} \mathrm{C}$ (DSMFW)

2 The DSMFW was mixed with $6 \%(\mathrm{w} / \mathrm{w})$ sulfuric acid at a solid-to-liquid ratio of 1:10 (w/w). The hydrolysis was performed at $155{ }^{\circ} \mathrm{C}$ for 30 minutes. The liquid fraction was analyzed using High Performance Liquid Chromatography as described by Rosander et al. (2016)
} 


\begin{tabular}{|c|c|c|c|}
\hline & & & market. \\
\hline \multirow{3}{*}{ 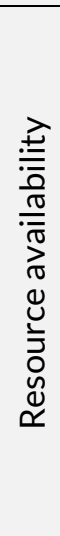 } & Benchmarking & $\begin{array}{l}\text { Which capacity is needed for } \\
\text { commercial production? }\end{array}$ & $\begin{array}{l}\text { Review of existing and planned SA } \\
\text { capacity today based on scientific } \\
\text { papers, news articles, and company } \\
\text { webpages. }\end{array}$ \\
\hline & Waste flow analysis & $\begin{array}{l}\text { Is there sufficient MFW in } \\
\text { Sweden for the target } \\
\text { production capacity? }\end{array}$ & $\begin{array}{l}\text { Data from Swedish national } \\
\text { statistics and analyses. }\end{array}$ \\
\hline & Scenario analysis & $\begin{array}{l}\text { Is there sufficient MFW in } \\
\text { Sweden for the target } \\
\text { production capacity given } \\
\text { political goals for reduced food } \\
\text { waste? }\end{array}$ & $\begin{array}{l}\text { Calculations based on data } \\
\text { collected for the waste flow } \\
\text { analysis complemented with } \\
\text { literature studies of related policy } \\
\text { documents. }\end{array}$ \\
\hline
\end{tabular}

\section{Feedstock Feasibility}

In Sweden, MFW originates from many different functions in society; for example households, retail markets and restaurants. Municipal waste management treatment plants or waste management companies hired by the municipality then treat the generated waste.

\subsection{MFW content}

Information about the composition of MFW from municipal solid waste in the literature is limited, especially when it comes to non-source separated feedstock. Previous studies also apply to other geographical regions than Sweden. Therefore, studies were conducted on MFW from a Swedish waste management company for comparison (Table 2). The MFW used was collected from Ragn-Sells AB and is of a complex character. The waste is composed of non-source separated household waste together with food from grocery stores, in the ratio of 2:1. At the facility, the waste is processed to form a liquid slurry: The incoming waste is crushed and packaging material and larger solids are removed. The final ratio of organic and inorganic material in this resulting slurry is unknown.

The composition and moisture content of the waste collected in the present study was analyzed and compared to analyses of MFW in the literature (Table 2). As seen in Table 2, the composition of the MFW slurry from municipal solid waste in Sweden, shows similarities to other MFW sources. In general, MFW is rich in carbohydrates, which constitute $40 \%$ of the waste. The carbohydrate content in Swedish slurry was determined to be $42 \%$ (w/w, dry basis) (Rosander et al. 2016). This shows the feasibility of using MFW slurry as a carbon and energy source for E. coli growth as sugar moieties can be made accessible for bacterial assimilation through hydrolysis. 
Table 2. Composition and moisture content of MFW reported by various sources

\begin{tabular}{|l|l|l|l|l|l|l|l|}
\hline Origin & $\begin{array}{l}\text { Carbohydrate } \\
(\mathrm{mg} / \mathrm{g})\end{array}$ & $\begin{array}{l}\text { Lipid } \\
(\mathrm{mg} / \mathrm{g})\end{array}$ & $\begin{array}{l}\text { Protein } \\
(\mathrm{mg} / \mathrm{g})\end{array}$ & $\begin{array}{l}\text { Phosphorous } \\
(\mathrm{mg} / \mathrm{g})\end{array}$ & $\begin{array}{l}\text { Moisture } \\
(\%)\end{array}$ & $\begin{array}{l}\text { Solids } \\
(\%)\end{array}$ & Reference \\
\hline $\begin{array}{l}\text { MFW } \\
\text { slurry, } \\
\text { Sweden }\end{array}$ & 420 & n.a. & 2203 & 0.34 & 91 & 9 & $\begin{array}{l}\text { This study, } \\
\text { (see also } \\
\text { Rosander } \\
\text { et al. 2016) }\end{array}$ \\
\hline $\begin{array}{l}\text { Canteen, } \\
\text { China }\end{array}$ & 332 & 150 & 103 & 3.9 & n.a. & n.a. & $\begin{array}{l}\text { Pleissner, } \\
\text { Lam et al. } \\
\text { 2013 }\end{array}$ \\
\hline $\begin{array}{l}\text { Canteen, } \\
\text { China }\end{array}$ & 427 & 67 & 111 & 1.6 & 80 & 19.6 & $\begin{array}{l}\text { Han, Liu et } \\
\text { al. 2015 }\end{array}$ \\
\hline $\begin{array}{l}\text { Dining } \\
\text { room, } \\
\text { China }\end{array}$ & n.a. & 124 & 213 & n.a. & 80 & 21 & $\begin{array}{l}\text { Yan, Li et } \\
\text { al. 2011 }\end{array}$ \\
\hline $\begin{array}{l}\text { Dining } \\
\text { room, } \\
\text { China }\end{array}$ & n.a. & $151-$ & $132-$ & n.a. & n.a. & $\begin{array}{l}11,97- \\
18,10\end{array}$ & $\begin{array}{l}\text { Wang, Ma } \\
\text { et al. 2008 }\end{array}$ \\
\hline $\begin{array}{l}\text { Household, } \\
\text { Greece }\end{array}$ & 122 & 119 & 105 & n.a. & n.a. & n.a. & $\begin{array}{l}\text { Matsakas, } \\
\text { Kekos et al. } \\
\text { 2014 }\end{array}$ \\
\hline
\end{tabular}

In addition to the composition and moisture content analysis, an elementary analysis of two fractions of MFW slurry was performed to investigate its complete potential, as shown in Table 3. A similar study of elementary composition of household food waste from the UK has been reported with a similar order, in percent dry weight: $45.7 \mathrm{C}, 3.4$ $\mathrm{N}, 0.71 \mathrm{~S}, 0.08 \mathrm{mg} / \mathrm{kg} \mathrm{P}$ (Esteves and Devlin 2010). As can be seen in Table 2, the carbon content is dominant in all MFW analyzed. The elementary analysis of nutrients present in MFW can be used to determine if the waste can be used to support the production of E. coli cell mass. This potentially supported production is expressed as supported cell dry weight in Table 3. The waste was a liquid slurry with a moisture content of $91 \%(\mathrm{w} / \mathrm{w})$. The slurry was fractionated with centrifugation to yield a solid and a liquid fraction. The elementary composition of each fraction and the supported cell dry weight is presented in Table 3 . The elementary requirement of the biomass itself was then used to calculate the supported cell dry weight of biomass that can be created from the waste. Hydrogen and oxygen are taken from the process liquid or the surrounding atmosphere, but all the other nutrients must be supplemented to the media.

From Table 3 it can be concluded that the compounds that probably limit the production of E. coli biomass are phosphorous and magnesium. These elements can thus be supplemented to the waste medium in order to optimize the amount of waste needed.

\footnotetext{
${ }^{3}$ Using conversion factor ( $\mathrm{N}$ to protein) of 6.25

(c) RISE Research Institutes of Sweden
} 
Table 3. Nutrient requirements based on cell dry weight (CDW) and elementary composition of MFW fractions with calculated supported cell dry weight per element

\begin{tabular}{|l|l|l|l|l|l|l|l|}
\hline \multirow{2}{*}{ Element } & \multirow{2}{*}{ Element in cell (\%) } & \multicolumn{4}{|l|}{ Content $\left(\mathrm{g} \mathrm{L}^{-1}\right)$} & \multicolumn{3}{l|}{$\begin{array}{l}\text { Supported cell dry weight } \\
\left(\mathrm{g} \mathrm{L}^{-1}\right)\end{array}$} \\
\cline { 3 - 8 } & & Slurry & Solid & Liquid & Slurry & Solid & Liquid \\
\hline $\mathrm{C}$ & 50 & 64.2 & 521 & 2.6 & 64 & 521 & 2.6 \\
\hline $\mathrm{N}$ & 14 & 3.5 & 29.6 & 1.3 & 25 & 211 & 9 \\
\hline $\mathrm{P}$ & 3 & 0.3 & 3 & 0.24 & 12 & 100 & 8 \\
\hline $\mathrm{S}$ & 1 & 0.5 & 2.03 & 0.086 & 52 & 203 & 8.6 \\
\hline $\mathrm{K}$ & 1 & 1.0 & 5 & 1.3 & 101 & 500 & 130 \\
\hline $\mathrm{Mg}$ & 0.5 & 0.1 & 1.1 & 0.085 & 12 & 220 & 17 \\
\hline
\end{tabular}

Due to the high moisture content of MFW, the concentrations of various nutrients in the slurry are low. Fractionation of the slurry and drying of the solid fraction resulted in a more concentrated fraction.

From an elementary analysis of a cell, the basal need of various elements can be calculated. If the cell is to be used as a production host, proper building material must be added for producing the product. In order for the cell to produce a product, for example SA, more nutrients are required than those for biomass. SA is produced from oxaloacetate (OAA) under anaerobic conditions in E. coli. OAA is an intermediate from the degradation of glucose (glycolysis). For each molecule of OAA, one molecule of $\mathrm{CO}_{2}$ is required to incorporate one carbon atom. Thus, to produce SA, both glucose and $\mathrm{CO}_{2}$ are required to meet the carbon requirement.

\subsection{Pretreatment of MFW to design an E. coli cultivation media for succinic acid production}

Since MFW once was meant for human consumption, it is likely that it also contains all the building blocks necessary for bacterial growth. However, the originating food consists of complex structures and may not be suitable for direct use as a substrate in bacterial cultivation. To increase the degree of accessible nutrients, polymeric structures must be degraded to monomeric building blocks. This can be achieved by applying hydrolysis. There are two main types of hydrolysis: chemical and enzymatic.

The primary groups of nutrients that need to be degraded are carbohydrates, proteins, and lipids. Carbohydrates and lipids can be used as a carbon source for bacterial growth. Carbohydrate hydrolysis generates a variety of sugar moieties while lipid degradation results in glycerol and fatty acids. Bacteria, such as E. coli, can often only utilize one carbon source at a time. Therefore, in this study, hydrolysis of only the carbohydrate fraction of MFW was applied.

In general, MFW has a high moisture content of approximately 80 \% (Song and Lee 2006, Yan et al. 2011, Han et al. 2015). This may result in a diluted hydrolyzate, and fractionation of MFW was applied to yield a liquid and a solid fraction (moisture content in the solid fraction was $30 \%$ ). The solid fraction had a high carbohydrate content of $42 \%$ (w/w, dry basis). Enzymatic hydrolysis of the solid fraction yielded a 
maximum of $86 \mathrm{~g} \mathrm{~L}^{-1}$ glucose. Hydrolysis of the liquid fraction yielded $30 \mathrm{~g} \mathrm{~L}^{-1}$ glucose (Rosander et al. 2016).

\subsection{E. coli growth conditions}

To explore if the MFW slurry from municipal solid waste supports the growth of E. coli, cultivating tests were conducted on both the liquid and the solid fraction (hydrolyzed).The tests showed that the growth of E. coli in the liquid fraction of MFW is restricted and trace elements must be supplemented to the media in order for growth to initiate (Rosander et al. 2016). With supplementation, the cells grew well in the liquid MFW with a generation time of approximately 2 hours. Only a short lag phase (< $2 \mathrm{~h}$ ) was detected and no prominent growth inhibition was displayed. Thus, no inhibiting compounds seem to be present in the MFW medium. After approximately 8 hours of cultivation and optical density at $600 \mathrm{~nm}$ (OD60o) of $9\left(\sim 3 \mathrm{~g} \mathrm{~L}^{-1}\right.$ cell dry weight), the growth rate ceased. The reason for this is unknown but is probably due to production of an intermediate metabolite that inhibited growth or an element that became limiting.

Instead of using the MFW as a complete growth media, single components can be used. In such a case, the other elements need to be supplemented to the medium. Rosander et al. 2016 applied enzymatic hydrolysis to the solid fraction of MFW and used the hydrolyzate as a carbon and energy source. By applying enzymatic hydrolysis with enzymes targeted for carbohydrate degradation, the concentration of sugar was increased to $86 \mathrm{~g} \mathrm{~L}^{-1}$ glucose and $20 \mathrm{~g} \mathrm{~L}^{-1}$ xylose. Then, the MFW hydrolyzate was applied as a carbon and energy source to E. coli cultivation medium. In repeated batch cultivation mode, a short lag phase was displayed upon the addition of the hydrolyzate. The cells were efficiently able to take up and grow on the glucose in the hydrolyzate. However, xylose accumulated. This can potentially become a problem due to inhibition if the concentration increases. Also, for production efficiency, it is important that all available sugars are utilized. For this reason, the hydrolyzate was used as feed in fedbatch cultivation mode with an exponential growth phase of $0.2 \mathrm{~h}^{-1}$. The lower growth rate resulted in an efficient uptake of both glucose and xylose.

\subsection{Variance in MFW content over time}

Glucose and xylose are the major sugar constituents of MFW hydrolyzate. To identify possible variations in time, the variance of sugar in different MFW batches, collected at seven occasions over a year, was analyzed (Figure 1). For the hydrolysis, a standard method using sulfuric acid was used for comparison. The soluble concentration of glucose and xylose varied from $0.6-12 \mathrm{~g} \mathrm{~L}^{-1}$ and $2-14 \mathrm{~g} \mathrm{~L}^{-1}$, respectively. In other words, there is quite a large variation in the soluble concentrations of sugars in the liquid fraction of MFW. For the hydrolyzate from the solid fraction, the corresponding values were $13-34 \mathrm{~g} \mathrm{~L}^{-1}$ and $6-11 \mathrm{~g} \mathrm{~L}^{-1}$, for glucose and xylose, respectively. However, except for batch 2014-JAN, the concentrations were relatively stable for the hydrolyzate. 
A

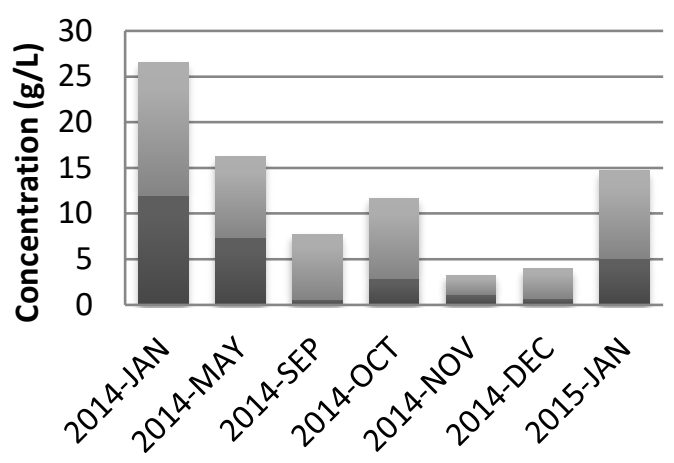

B

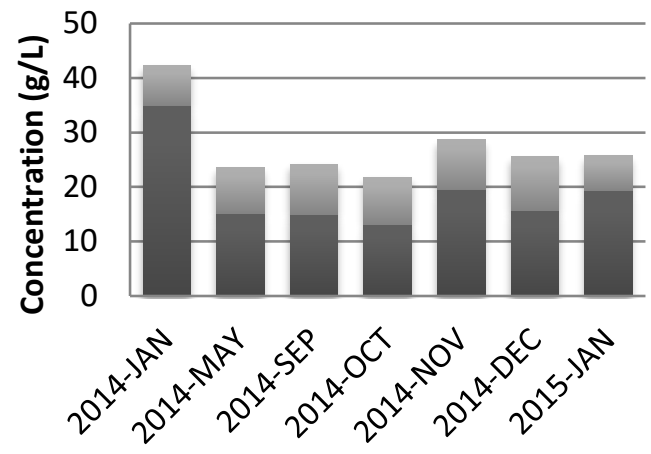

Figure 1. Variance of glucose and xylose in the liquid fraction of MFW (A) and solid acid hydrolyzate of MFW (B). Glucose: light grey, xylose: dark grey.

To summarize the findings in Section $3.1-3.5$, the feedstock feasibility assessment shows the potential use of MFW as a resource for bacterial cultivation. The feedstock is rich in carbohydrates, and, after hydrolysis, a hydrolyzate rich in sugar can be obtained from the solid fraction. There remain challenges to address using the liquid fraction of MFW as a sole nutrient source. Instead, the solid fraction hydrolyzate can be used as a carbon and energy source, although process development is required. There is a natural variance in the sugar composition of MFW, although the variation in the hydrolyzate was not significant except for one of the batches analyzed.

\section{Societal Drivers and Barriers}

The viability of SA production from MFW is not only determined by the ability to process the feedstock in an efficient manner, but also by policies, norms, values, and entrepreneurial activities in society. This section will elaborate on possible drivers and barriers connected to policy, social acceptance, and current as well as potential future actors driving SA development.

\subsection{Policy}

Waste is a highly controlled and managed resource in a political context. In a review of the current policy landscape for food waste and food waste valorization, more than 100 policy documents and initiatives, such as directives, strategies, and political targets associated with food waste handling in the EU (e.g. European Commission 2008b, European Commission 2010, European Commission 2011) and Sweden (e.g. Miljö- och energidepartementet 1998, Svensk författningssamling 2011, Swedish Environmental Protection Agency 2012) were identified. These instruments range from regulatory bans to political goals, recommendations, and economic incentives (see e.g. Nilsson and Sundberg 2009). Some policies directly limit, encourage, or determine the use of 
waste treatment options for certain types of food waste. Sweden, for example, has had a landfill ban for organic wastes since 2005 (Svensk författningssamling 2001) meaning it must be biologically treated or sent to incineration. There are also regional differences where some municipalities in Sweden encourage biological treatment through reduced waste fees for separation, while others have either no or mandatory separation of food waste. The trend is towards more source separation of food waste (Avfall Sverige 2016a).

Political action affects the amount and quality of MFW available and prevention and reduction of food waste is high on the European policy agenda. The Waste Framework Directive (European Commission 2008b) outlines not only the waste hierarchy but also sets a target that $50 \%$ of household waste and similar material is to be prepared for reuse or recycled by 2020. Similarly, in the Roadmap for a Resource Efficient Europe (European Commission 2011), food is recognized as a "key sector" and there is a call to: "halve the disposal of edible food waste in the EU by 2020". Similar identification of food waste as a key area of concern is expressed also on the national level in Sweden (Swedish Environmental Protection Agency 2015). A specific goal has been set for increased resource efficiency in the food chain stating that,"Measures shall be implemented so that by 2018 , at the latest, a minimum of $50 \%$ of the food waste from households, institutional kitchens, supermarkets, and restaurants is sorted separately and treated biologically so that plant nutrients are recovered. Moreover at least $40 \%$ of the food waste shall be treated so that energy is recovered as well (Swedish Environmental Protection Agency 2014 author's translation). Communication from governmental agencies and waste management associations (Swedish National Food Agency et al. n.d.) reveals that this goal is interpreted as meaning that at least $40 \%$ of food waste is to be treated through anaerobic digestion and a maximum of $10 \%$ is to be treated through composting. This interpretation does not include prospective techniques such as microbial cultivation to generate platform chemicals.

In contrast to other feedstock, waste is not freely offered on a market but is restricted by waste ownership structures, long-term, investments and contracts. Swedish municipalities have ownership of household waste (Miljö- och energidepartementet 1998), and they are also responsible for its collection and treatment (Avfall Sverige 2015). In recent years, there has been interest in waste incineration on commercial grounds, where waste is seen as one fuel among others. Incinerators in Sweden are mainly operated by municipally controlled entities, and, as of today, there are about 80 facilities in Sweden that incinerate waste from household and other sources (Swedish Environmental Protection Agency 2016). Given that incinerator capacity has been expanded greatly in Sweden in the past 10 years, there is now an overcapacity in the Swedish incinerator stock of about 1.5 million tons (Sahlin et al. 2013). Many municipalities and incorporated inter-municipal bodies have also invested in biogas facilities or have long-term contracts of supply to actors that own biogas sites (informant interviews). This feedstock ownership structure and investment history poses a barrier to investments in potential new sites for waste valorization.

There are also policy initiatives in other sectors that are likely to affect whether or not, and the extent to which, MFW will be used for the production of chemicals and materials. Key sectors influencing the feasibility of bio-based SA development are transport, chemicals, and materials, which are all dominated by fossil feedstock. Fossil dominance is partly a result of economics of scale but also a result of a variety of 
regulations, norms, and standards that, for decades, have been adjusted to fit and support the various properties of fossil technology value chains (Ulmanen 2013). This makes it very hard for radically different and novel technologies, such as bio-based SA, to develop.

However, recently fossil dominance has been challenged, which has stimulated the development of renewable alternatives, which, in turn, influences the development of bio-based SA. For instance, the political ambition to increase the share of renewable energy in the transport sector has a strong influence on the prospects of using food waste for chemicals and materials. There are many institutions promoting the use of biomass, such as food waste for fuel production. A key example is the EU Renewable Energy Directive (European Commission 2009), which mandates that 20\% of all energy usage in the EU, including at least 10\% of all energy for road transport fuels, is to be produced from renewable sources by 2020. Fuels based on biomass waste are favored in regard to this target (ibid.).

In Sweden, the development of waste-based biofuels, such as cellulose ethanol and biogas, has been supported with a range of economic incentives and support schemes over the last three decades. These include energy- and CO2-tax exemptions for various biofuels and incentives that stimulate the market for environmental cars and supply of alternative fuels (SFS 2005, SOU 2013). In 2008, Sweden adopted a vision of a fossilindependent vehicle fleet by 2030 (Regeringskansliet 2008), in which biogas is one alternative to fossil-based fuels. This, in combination with direct economic incentives for anaerobic digestion and biogas production through investment programs supporting biogas and other gaseous fuels (Nilsson and Sundberg 2009, Bisaillon et al. 2013), has further contributed to the current dominance of biogas production from MFW in the country.

Compared to biofuel, bio-based chemicals and materials have, thus far, been much less affected by Swedish and European policy incentives. There are currently no dedicated political incentives for the development of bio-based chemicals and related products (Swedish Energy Agency 2014, Nova institute 2015a). It is often argued that the many policy incentives for bioenergy and biofuels on the national and European levels have hindered the development of bio-based chemicals and materials by creating unequal market conditions (informant interviews; Nova institute 2015a). Biofuel and bioenergy incentives have led to a higher demand and a higher price for biomass, which, in turn, implies limited access to biomass for the development of chemicals and materials sector and, thus, less interest from investors (ibid.).

To date, the only policy support for bio-based chemicals and materials are declarations of intent in various strategy documents (Nova institute 2015a). Examples in the EU include the Bioeconomy Strategy (European Commission 2012) and the Lead Markets Initiative for bio-based products (European Commission 2008a). The latter is particularly interesting considering its ambition to promote bio-based products by developing: a) regulations promoting market development through incentives, facilitate specific product development, and create access to biomass; b) stimuli for public procurement; c) standards for, e.g. bio-based content, sustainability, LCA methods, and communication; and d) a variety of complementary issues, such as R\&D (Nova institute 2015a). So far progress has been made in the area of standards and public procurement (European Commission 2016a, SIS 2016). Sweden does not have a bio-economy 
strategy, but the intent to develop biomaterials has been expressed in the Swedish Research and Innovation Strategy for a bio-economy among others (Formas 2012).

Support for bio-based building block chemicals and materials is also available in the form of international and national funding schemes for research and innovation (Nova, 2015). However, in Sweden only a small number of research projects involving highvalue platform chemicals have gained funding since 2000, and these have mainly been related to wood- and crop-based raw materials and chemicals in line with existent biofuel developments, such as ethanol (informant interviews).

To summarize, policy support for bio-based chemicals, such as SA and related materials, is more or less nonexistent. Current policy framework continues to enable the dominance of fossil fuels in the chemicals and materials sectors. In the transport sector, policy has been introduced to stimulate renewable alternatives, such as biofuels and bioenergy. However, the lack of similar support for bio-based chemicals and materials creates unequal market conditions, particularly with regard to feedstock access. While policy support for bio-based chemicals and materials is under development in order to create a level playing field between biofuels/bioenergy and green chemicals, future feedstock access is likely to remain a challenge due to conflicting political objectives and current infrastructure investments.

\subsection{Social acceptance}

Informal institutions, such as social norms and values, may also influence the prospects of using food waste for the production of bio-based chemicals. There is, for example, a tradition and culture in Europe to have leftover food (European Commission, 2010b), which upholds a stream of food waste for feedstock. In addition, there is a positive attitude in society towards replacing fossil-based raw materials with renewable ones, as this is considered an important step towards sustainable development, not least by companies aiming for green chemistry (see e.g. Sheldon 2014, Kemiföretagen i Stenungsund n.d.).

Some renewable feedstock is more legitimate than others. The international debate on 'food versus fuel', i.e. about the use of arable land for other purposes than food production has been intense (see e.g. HLPE 2013). The aftermath of this debate indicates that the general public regards waste or lignocelluloses as a more legitimate feedstock for industrial products than food crops, despite the fact that the most common feedstock comes from refined sugars (sucrose, glucose and fructose), starch, and beet or cane molasses (Jansen \& van Gulik, 2014). In light of the feedstock discussion, producers of bio-based SA have indicated an ambition to shift from cultivated crops to waste streams, if possible (BioAmber 2016). This indicates that biobased SA derived from food waste might be more legitimate than bio-based SA from corn, for example.

Societal norms and values may also affect the premises for the acceptance of specific technologies used. Interviewees, for example, expressed a concern that public opinion against genetically modified organisms (GMO) may hamper Swedish production of SA, considering that it is expected to use genetically modified E. coli bacteria. In fact, according to informant interviews, there is a recent case in which public resistance has 
led to the termination of a bio-processing production site in southern Sweden that intended to use GMOs.

\subsection{Current and future actors driving development}

To bring about novel technology development and market implementation, it is necessary that actors along the whole technology value chain are aligned in a network that strives towards a common goal of advancing the technology. Considering that commercial production of SA from MFW is merely an idea, there is not yet an aligned network of actors that actively work throughout the value chain. However, the above mentioned FORMAS research project (see Section 2) constitutes a network of actors with the ambition to investigate high-value chemicals from food waste in which SA is identified as a potential future option. This can be seen as a starting point for a potential future SA network. These and additional actors are expected to be useful in the future realization of a potential SA value chain from MFW to polymer products and related markets.

By means of a workshop, the potential actors that could contribute to a future SA value chain have been mapped. This map reveals that actors with the knowledge, infrastructure, and technology needed to realize a full value chain for SA from MFW do exist. However, currently they are part of different technology networks related to various biofuels and fossil fuels, chemicals, and materials. These potential actors' close association with other technologies is likely to influence the prospects of SA production both positively, by contributing to synergies, and negatively, as a result of competition.

Considering feedstock processing, the development of biogas has stimulated the setup of a waste collection infrastructure, which potentially could facilitate future feedstock processing for bio-based SA (informant interviews; workshops). Nevertheless, the current norms and policies in society steer this feedstock towards biogas production only (see Section 4.1). In the conversion to an intermediary, biofuel and fossil fuel actors have developed relevant chemical processing infrastructure. A potential barrier is that a large share of the available infrastructure is optimized for fossil feedstock, which makes fossil products easier and cheaper to produce, and also the norm to which new products are compared (informant interviews; see also Swedish Energy Agency 2014). There may also be competition from other bio-based polymers (informant interviews; workshops), although bio-polymers with different properties and applications are likely to aid each other in the development of a bio-based polymer market.

Platform chemicals are sold on an international market, and bio-based SA is one of the platform chemicals that is currently the most popular among chemical companies globally (Lane, 2015). Bio-based SA shows indications of being one of the most dynamic developments and having the largest growth rate among bio-based building blocks (Choi et al. 2015, Nova institute 2015a). This may be related to a potentially large volume of applications in polyesters and polyamides, which represent areas where the demand for bio-based alternatives are expected to grow (ibid. see also Sheldon 2014). An additional sign of development is current examples of bio-based SA competing with their petro-based counterpart (Nova institute 2015a, Ahn et al. 2016). 
The total world market for SA (fossil SA included) was about 30000 - 50 ooo tons in 2013 (NNFCC 2013). According to Nova Institute (2015a), the global production capacity of bio-based SA has increased over time, from about 3 ooo tons in 2011 to 30 ooo tons in 2013. Considering the many bio succinate production plants under construction, a capacity of around 390 ooo tons is predicted for 2020. As the technology for the bio-based production of SA improves, it is also expected to play a larger role as a building block chemical with a substantial market increase as a result. Some experts expect a potential market of up to 700 ooo tons bio-based SA per year in 2020 for this application (Choi et al. 2015).

\section{Resource Availability}

Societal aspects aside, the question remains whether there is sufficient food waste to supply a commercial site in Sweden. This issue has been addressed below through a capacity benchmark of current industrial production along with statistics and scenarios on current material flows of MFW.

\subsection{Targeted production capacity}

The economic feasibility of a production unit for bio-based SA depends on a range of factors. These include total capital investment and the cost of raw materials, utilities, labor, and maintenance as well as revenues from products and by-products produced (Lam et al. 2014). The co-production of platform chemicals, materials, and biofuels in integrated bio refineries is also likely to provide a higher return on investment (International Energy Agency 2013, Sheldon 2014). As the technology of the case study is yet premature, data for a techno-economic assessment of a specific facility is not available, and, thus, no profitable or optimal production capacity has been calculated. Nevertheless, a benchmark by Cok et al. (2014) of companies and industrial consortia developing industrial production of bio-based SA shows a range of production capacity on existing and planned sites from 3000 to 77000 tons per year, with 10000 tons and above as the absolute majority (cf. also Jansen and van Gulik 2014, Lane 2015). Given that a production process often requires a certain size to be economically feasible, it is assumed in the following sections that a commercial plant will need to produce at least 10 ooo tons of SA per year.

\subsection{Amounts of MFW in Sweden}

Food waste can be classified in different fractions in several ways. The Swedish EPA uses the terms inevitable and avoidable food waste (Swedish Environmental Protection Agency 2013), where inevitable food waste is defined as inedible parts, such as peels and bones. Avoidable food waste is defined as edible food waste caused by mismanagement or technology failure in any part of the food chain, such as surplus or malfunctioning production, inappropriate storage or transportation, lacking or undeveloped purchasing routines, or exceeded expiration dates. The amount of food wasted and the share of avoidable food in each fraction, differs among different stages in the food value chain, as seen in Figure 2. 


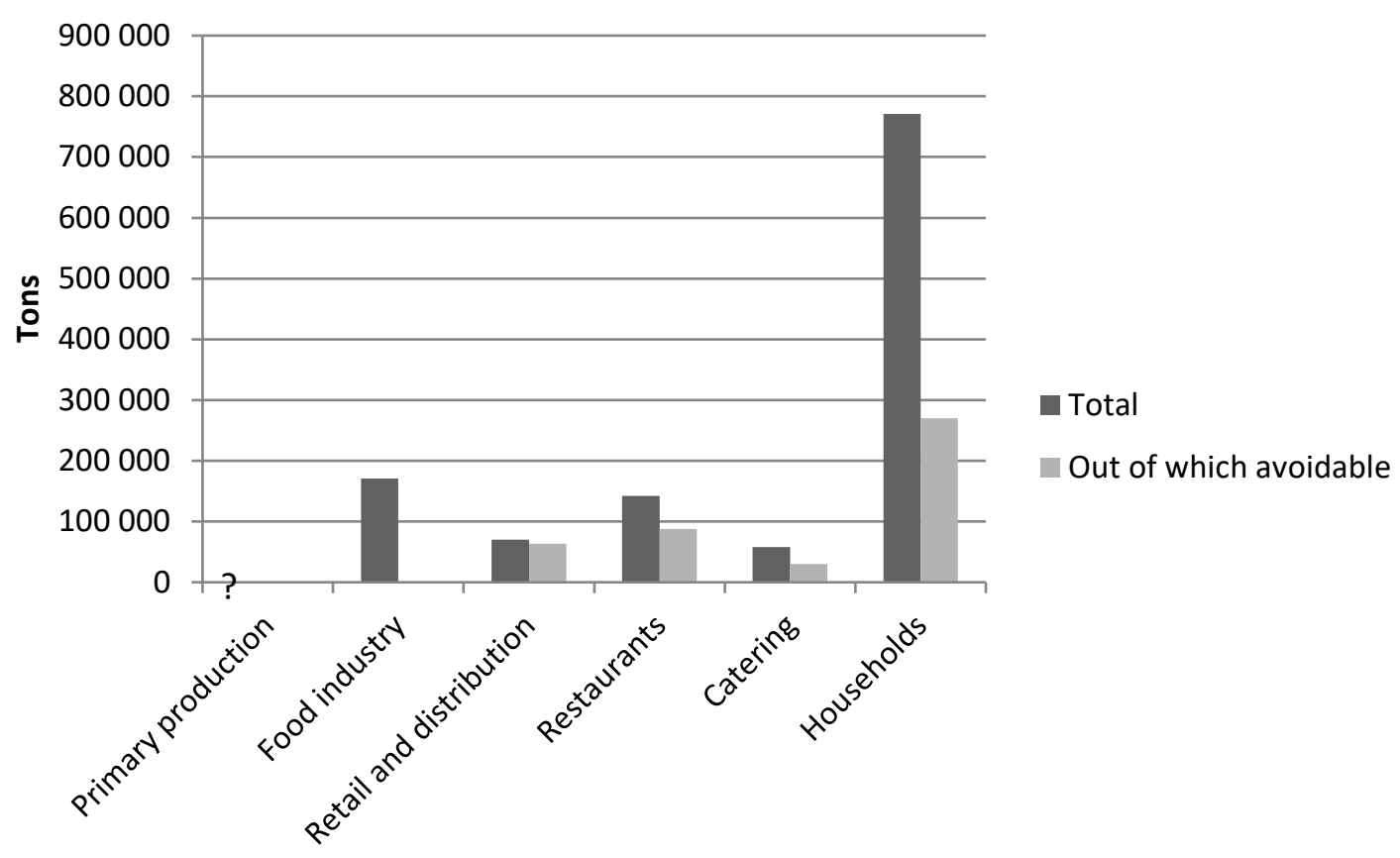

Figure 2. Amount of food waste in Sweden in 2012 (Swedish Environmental Protection Agency 2013). For the food industry, only edible food waste is included.

The total amount of food waste shown in Figure 2 is 1211 ooo tons, which corresponds to about $127 \mathrm{~kg}$ per person and year. MFW is assumed to make up a majority of the food waste from households, catering, restaurants, and retail and distribution. These four categories represented 1041000 tons of waste in Sweden in 2012 (Swedish Environmental Protection Agency 2013). In the following sections the entire fraction from these sources will be accounted as MFW.

\subsection{Feedstock potential to support production of 10000 tons succinic acid}

To calculate the amount of MFW needed to produce a total of 10 ooo ton bio-based SA, an example production system was chosen. The method of SA production and the efficiency of that process will naturally affect the amount MFW needed. A comparison was made of processes found in the literature (Table 4). A suitable example process was chosen based on the productivity and yield of SA using various E.coli strains.

As seen in Table 4, the two processes with the highest yield and productivity are the ones presented by Vemuri et al. (2002) and Jantama et al. (2008). These two processes do not differ in choice of carbon source, which was glucose, however, the cultivation technique differs: A dual-stage fed-batch was used by Vemuri et al. (2002) while an anaerobic batch process was used by Jantama et al. (2008). Both processes show promise for the industrial production of bio-based SA and were compared and used for calculations (Table 5). 
Table 4. Performance of bio-SA production using various E. coli strains

\begin{tabular}{|c|c|c|c|c|c|c|c|c|c|}
\hline Strain & Strategy & $\begin{array}{l}\text { Carbon } \\
\text { source }\end{array}$ & $\begin{array}{l}\text { Time } \\
\text { (h) }\end{array}$ & $\begin{array}{l}\text { CDW (g } \\
\left.\mathrm{L}^{-1}\right)\end{array}$ & $\begin{array}{l}\text { SA } \\
\text { concentra } \\
\text { tion }\left(\mathrm{g} \mathrm{L}^{-1}\right)\end{array}$ & $\begin{array}{l}\text { Yield g } \\
\text { gGlc }^{-1}\end{array}$ & $\begin{array}{l}\text { Vol. } \\
\text { prod. } \\
\text { gsa }{ }^{-1} \\
\mathrm{~h}^{-1} \\
\end{array}$ & $\begin{array}{l}\text { Spec. } \\
\text { prod. } \mathrm{mg} \\
\text { gcDW }^{-1} \mathrm{~h}^{-1}\end{array}$ & Ref. \\
\hline AFP111 & $\begin{array}{l}\text { Dual- } \\
\text { stage, } \\
\text { fed- } \\
\text { batch }\end{array}$ & Glucose & 76 & 10.2 & 99.2 & 1.16 & 1.3 & 127 & $\begin{array}{l}\text { Vemuri } \\
\text { et al. } \\
2002\end{array}$ \\
\hline $\begin{array}{l}\text { HL2765 } \\
9 \mathrm{~K}\end{array}$ & $\begin{array}{l}\text { Aerobic, } \\
\text { fed- } \\
\text { batch }\end{array}$ & Glucose & 59 & $\begin{array}{l}\text { OD600 } \\
354\end{array}$ & 58.3 & 0.55 & 0.98 & 89 & $\begin{array}{l}\text { Lin et } \\
\text { al. } \\
2005 \\
\end{array}$ \\
\hline $\begin{array}{l}\text { SBS550 } \\
\text { MG } \\
\text { (pHL413 } \\
+ \text { pDHK2 } \\
\text { 9) }\end{array}$ & $\begin{array}{l}\text { Dual } \\
\text { stage, } \\
\text { batch }\end{array}$ & Glucose & 24 & - & 18.89 & 1 & 0.79 & - & $\begin{array}{l}\text { Sánche } \\
\text { z et al. } \\
2005\end{array}$ \\
\hline KJ134 & $\begin{array}{l}\text { Anaerobi } \\
\text { c, batch }\end{array}$ & Glucose & 95 & 2.3 & 71.6 & 1 & 0.75 & 324.9 & $\begin{array}{l}\text { Jantam } \\
\text { a et al. } \\
2008\end{array}$ \\
\hline
\end{tabular}

The calculations of MFW needed were based on the elementary composition of a generic E. coli cell (Table 3) and the amount of precursor (glucose) needed for SA production. In this study, only the need for $\mathrm{C}$ and $\mathrm{N}$ was considered. The amount of $\mathrm{C}$ needed from $\mathrm{CO}_{2}$ fixation was not included in the calculations. The estimated concentration of $\mathrm{C}$ and $\mathrm{N}$ in the slurry was based on results from the elementary analysis and fractionation and moisture content analysis of Swedish slurry (as presented in Section 3).

Table 5. Estimated amount MFW slurry (based on $\mathrm{N}$ and $\mathrm{C}$ ) required to yield 10000 tons biobased SA using two different processes. Degree of hydrolysis is not considered

\begin{tabular}{|l|l|l|l|l|l|}
\hline & \multicolumn{2}{|l|}{ Growth stage } & \multicolumn{2}{l|}{ Production phase } & Total \\
\hline \hline & $\begin{array}{l}\text { Element } \\
\text { required } \\
\text { (ton) }\end{array}$ & $\begin{array}{l}\text { Slurry } \\
\text { required } \\
\text { (ton) }\end{array}$ & $\begin{array}{l}\text { Element } \\
\text { required } \\
\text { (ton) }\end{array}$ & $\begin{array}{l}\text { Slurry } \\
\text { required } \\
\text { (ton) }\end{array}$ & $\begin{array}{l}\text { Slurry } \\
\text { required } \\
\text { (ton) }\end{array}$ \\
\hline Vemuri et al. (2002) & \multicolumn{7}{l|}{} & \\
\hline C & 1000 & 16000 & 3500 & 54000 & 70000 \\
\hline N & 140 & 41000 & - & - & 41000 \\
\hline Jantama et al. (2008) & 320 & 5000 & 4000 & 62000 & 67000 \\
\hline C & 45 & 13000 & - & - & 13000 \\
\hline N &
\end{tabular}

The process developed by Vemuri et al. (2002) is a two-stage process. In the first stage, cells are grown. In the second stage, the production of SA is initiated, and a glucose feed is started and cell growth is stopped. As seen in Table 5, the amount of nitrogen is the limiting factor in the first cell growth phase. To satisfy the need for nitrogen,

\footnotetext{
${ }^{4}$ Optical density (OD) measured at $600 \mathrm{~nm}$

(c) RISE Research Institutes of Sweden
} 
approximately 41 ooo tons of MFW are needed to produce enough cells to generate 10 ooo tons of SA in the production phase. To satisfy the carbon need, 16 ooo tons are needed. If 41000 tons of MFW are added in the first stage, residual carbon will be present in the solution. When the feed starts, it is possible that the yielded SA will be affected negatively. To solve such a problem, MFW could be added to solely support the carbon need and the difference in nitrogen could be added from other sources.

In the SA production stage, the system is fed with a concentrated glucose solution of $500 \mathrm{~g} \mathrm{~L}^{-1}$ (corresponds to $\sim 200 \mathrm{~g} \mathrm{~L}^{-1} \mathrm{C}$ ). As the concentration of carbon in the slurry is $64 \mathrm{~g} \mathrm{~L}^{-1}$, the concentration of glucose in the slurry must be increased. The slurry would need to be concentrated approximately 3 times to meet the required concentration. This would introduce technical methods that can both be cost and energy demanding. To satisfy the total carbon demand in the process developed by Vemuri et al. (2002), 70 ooo tons of MFW are required.

In the process presented by Jantama et al. (2008), a lower amount of both nitrogen and carbon is needed to generate the required biomass, as the yield of SA per cell weight is higher. The process is simpler, compared to Vemuri et al. (2002). In this process, a batch mode is applied where all nutrients are present from the start. 13 ooo tons of nitrogen and 5000 tons of carbon are required for cell growth. For the production of SA, an additional 62000 tons of MFW are needed, giving a total of 67000 tons to support the carbon need. This process uses a concentration of $100 \mathrm{~g} \mathrm{~L}^{-1}$ glucose $(\sim 40 \mathrm{~g}$ $\mathrm{L}^{-1}$ carbon) in the medium. For this reason, the slurry must be concentrated approximately 1.5 times, which is much less than in the process developed by Vemuri et al. (2002).

The above amounts are calculated from the elementary composition of MFW with respect to $\mathrm{C}$ and $\mathrm{N}$. However, the elements will be locked in complex structures and may not be accessible for bacterial growth and uptake. For the nutrients to be available for E. coli uptake, the complex structures must be degraded into simple monomers. Therefore, hydrolysis of the waste is required. It is reasonable to assume that approximately $60 \%$ of the waste can be made accessible through hydrolysis.

For the process developed by Jantama et al. (2008), taking into account that hydrolysis is required, a total of approximately 110 ooo tons MFW are needed to support the production of 10 ooo tons SA, and for the process developed by Vemuri, approximately 120 ooo tons are needed.

\subsection{Perspectives on feedstock potential}

The above section shows that about 120 ooo tons of MFW were needed to support the production of 10 ooo tons of SA based on $\mathrm{N}$ and $\mathrm{C}$ under optimal conditions and a hydrolysis rate of $60 \%$. Given the amount of food waste in Sweden as shown in Table 6, this is on par with all food waste from restaurants in 2012, or $15 \%$ of all food waste from households the same year. $15 \%$ may sound like a small share, but Sweden is a large country relative to its population, and households are spread over a large geographic area. 
Table 6. Food waste in Sweden 2012 (calculated from Swedish Environmental Protection Agency 2013)

\begin{tabular}{|l|l|l|l|}
\hline Source & $\begin{array}{l}\text { Food waste } \\
\text { (tons) }\end{array}$ & Share avoidable & $\begin{array}{l}\text { Without avoidable food } \\
\text { waste }\end{array}$ \\
\hline \hline Households & 771000 & $35 \%$ & 500000 \\
\hline Catering & 58000 & $52 \%$ & 28000 \\
\hline Restaurants & 142000 & $62 \%$ & 54000 \\
\hline Retail and distribution & 70000 & $91 \%$ & 6000 \\
\hline Total & 1041000 & & 588000 \\
\hline
\end{tabular}

In the more densely populated areas of western Sweden and the Stockholm region, waste treatment facilities for biological waste from retail and households operate with an allowed top capacity of about 20-30 ooo tons of organic waste per year (see e.g. Stockholms Tingsrätt 2002, Vänersborgs Tingsrätt 2015). In this perspective, 120000 tons of MFW is a substantial amount that would require an uptake from several waste handling facilities. With the high water content in food, there is probably low economy in additional transportation of the waste.

The political ambition in Sweden, mentioned above, is to minimize avoidable food waste. Table 6 shows a scenario of amounts of food waste available given a total elimination of avoidable food waste. In this scenario, it can be seen that catering, restaurants, and retail will not be sufficient for the production capacity aimed for. Further, 10 ooo tons of SA would require $24 \%$ of all organic household waste in Sweden for feedstock supply. This high share of a widely distributed feedstock calls for the need to explore ways to combine MFW with other feedstocks to support not only the $\mathrm{C}$ needed but possibly also the $\mathrm{N}$, depending on the process design chosen.

\section{Summary of Findings}

Table 7 summarizes the findings from Sections $3-5$.

Table 7. Main conclusions from questions

\begin{tabular}{|c|c|c|}
\hline & Question & Conclusion \\
\hline \multirow{3}{*}{ 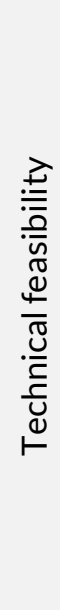 } & $\begin{array}{l}\text { What substances/molecules does MFW } \\
\text { contain? Are they suitable for E. coli } \\
\text { growth? }\end{array}$ & $\begin{array}{l}\text { The MFW contains required molecules for } \mathrm{E} \text {. } \\
\text { coli (N, C, P...). However, for efficient } \mathrm{C} \text { use, } \\
\text { additional } \mathrm{N} \text { must be added. No growth } \\
\text { inhibition was detected }\end{array}$ \\
\hline & $\begin{array}{l}\text { Can the carbon sources in MFW be made } \\
\text { more accessible for E. coli uptake? }\end{array}$ & $\begin{array}{l}\text { Carbohydrate hydrolysis can yield } 88 \mathrm{~g} \mathrm{~L}^{-1} \\
\text { glucose and } 20 \mathrm{~g} \mathrm{~L}^{-1} \text { xylose, glucose, which can } \\
\text { be used as a carbon source in fed-batch } \\
\text { cultivations. }\end{array}$ \\
\hline & Does E. coli grow on MFW? & $\begin{array}{l}\text { The liquid fraction of MFW supports growth up } \\
\text { to a cell dry weight (CDW) of } 3 \mathrm{~g} \mathrm{~L}^{-1} \text { without } \\
\text { the addition of any extra macro nutrient. The } \\
\text { solid phase can be used as a carbon source in } \\
\text { either batch or fed-batch conditions through } \\
\text { hydrolysis. }\end{array}$ \\
\hline
\end{tabular}




\begin{tabular}{|c|c|c|}
\hline & Question & Conclusion \\
\hline & $\begin{array}{l}\text { Is the water content in MFW optimal for E. } \\
\text { coli growth? }\end{array}$ & $\begin{array}{l}\text { The high moisture content results in liquids that } \\
\text { are too dilute for industrial production. }\end{array}$ \\
\hline \multirow{3}{*}{ 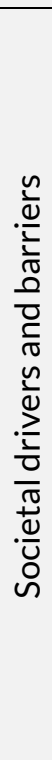 } & $\begin{array}{l}\text { How do existing formal rules and } \\
\text { regulations influence the availability and } \\
\text { use of MFW for SA production? }\end{array}$ & $\begin{array}{l}\text { Policies do not directly prohibit the use of } \\
\text { MFW for SA production for most applications, } \\
\text { but neither do they encourage it. Initiatives, } \\
\text { investments, and subsidies in other sectors, } \\
\text { such as transport fuels, direct feedstock and } \\
\text { human capital to other uses (mainly biogas). }\end{array}$ \\
\hline & $\begin{array}{l}\text { How do norms and values in society } \\
\text { influence the prospects of using MFW for } \\
\text { SA production? }\end{array}$ & $\begin{array}{l}\text { Perceptions of the circularity of biomass and } \\
\text { the valorization of food waste are generally } \\
\text { positive, which is likely to stimulate } \\
\text { development. A potential barrier is the fear of } \\
\text { GMO. }\end{array}$ \\
\hline & $\begin{array}{l}\text { Can the right type of actors be mobilized } \\
\text { to realize a SA value chain, from supply to } \\
\text { demand? }\end{array}$ & $\begin{array}{l}\text { There are yet no actors fully committed to the } \\
\text { development of bio-based SA. There are only } \\
\text { separate initiatives that are not aligned. } \\
\text { However, there are potential actors that could } \\
\text { be mobilized for bio SA development in the } \\
\text { future. A global market demand for bio- } \\
\text { polymer products is expected in the future. }\end{array}$ \\
\hline \multirow{3}{*}{ 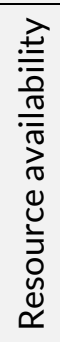 } & $\begin{array}{l}\text { Which capacity is needed for commercial } \\
\text { production? }\end{array}$ & $\begin{array}{l}\text { Most existing plants have a production capacity } \\
\text { of at least } 10000 \text { tons bio-based SA per year }\end{array}$ \\
\hline & $\begin{array}{l}\text { Is there sufficient MFW in Sweden for the } \\
\text { target production capacity? }\end{array}$ & $\begin{array}{l}\text { There is more than needed if all MFW in } \\
\text { Sweden is put to use, but not at each individual } \\
\text { facility. }\end{array}$ \\
\hline & $\begin{array}{l}\text { Is there sufficient MFW in Sweden for the } \\
\text { target production capacity given political } \\
\text { goals for reduced food waste? }\end{array}$ & $\begin{array}{l}\text { There is sufficient MFW in Sweden all in all, but } \\
\text { it would be distributed among many sites. }\end{array}$ \\
\hline
\end{tabular}

As seen in Table 7, the answer to how viable bio-based SA production is as an added pathway for MFW is different depending on the perspective used. The analyses of feedstock feasibility reveal that there are nutrients of the right kind in the feedstock, but that their relative ratio indicates that it might be advisable to combine existing waste with other feedstock or nutrients to result in a more efficient cultivation media. Also, the inherent forms and high water content of MFW point to a possible need for extensive pre-treatment. Similarly, the resource availability assessment shows that there is sufficient food waste in Sweden for a full-size plant for SA, however, the resource is spread over large geographic area, which makes it doubtful whether it is financially feasible to gather the amounts needed at a specific site.

The analysis of societal drivers and barriers shows that there are institutions in society that both support and hamper the development of bio-based SA. Key actors with relevant knowledge exist but these are not aligned to realize the production of SA from MFW. Biogas production is a highly institutionalized route for MFW valorization in Sweden, and its dominance is further fueled by existing organizational structures for waste management, political ambitions to use biogas as a means to meet sustainability goals in other areas, and a lack of policy support for bio-based chemicals and materials. This means that bio-based SA from food waste most likely lacks sufficient institutional support for development in Sweden. Policy instruments as well as joint commitment of and collaboration between key actors, such as researchers, feedstock owners, chemical process converters, and producers of end products, are crucial for further development. 


\section{Discussion}

As can be seen in the results above, different perspectives reveal different insights into the viability of using MFW for bio-based SA production. This section contains a discussion of this finding along with further research needs.

\subsection{The need for interdisciplinary systems approaches}

The three perspectives used in this study all add important insights to clarifying the prospects for the development of bio-SA from MFW. While assessments on feedstock feasibility and resource availability provide insights into biotechnological and physical constraints and possibilities, analyses of policy initiatives, social acceptance, and actors contribute insights into the likelihood of future development.

The different analyses conducted in this study not only contribute to identifying strengths and weaknesses derived from each perspective in isolation but add to a bigger picture of dynamic interrelations: One example is that scientific advances of potential feedstock conversion routes influence the kind of waste flows that are possible resources for the chemical industry, at the same time as competition with and institutions of other sectors determine actual resource availability. Such interrelations and dynamics between perspectives indicate that there is a need for interaction between researchers in different disciplines to obtain the nuanced systems perspective necessary to deliver a more holistic view.

As outlined in Section 2, the analysis of social drivers and barriers was inspired by a technological innovation systems (TIS) perspective. It may be argued that the TIS framework already includes sufficient analysis of technology and resources and, thus, could serve as a comprehensive analytical framework in itself. The framework is, however, mainly developed for existing technological innovation systems in which the technology innovation is already defined. This is not the case for bio-SA from MFW in Sweden, for which more insight into technical and resource aspects is necessary. In addition, to the knowledge of the authors, the existence of a sufficient amount of feedstock vital for the system to function is usually not fully accounted for in TIS studies (one of the few exceptions being Swedish Energy Agency 2014). Another commonly known limitation of TIS studies is that they do not question the desirability of the technology in a future sustainable society (Weber and Rohracher 2012). TIS, consequently, has limitations, particularly for analyzing immature systems, and the methodology would benefit from a larger adaptation to prospective cases and a stronger emphasis on resource availability to better suit challenges faced in resource management and the bio-economy.

Among biotechnology researchers and engineers, on the other hand, a common perception seems to be that economic viability is the supreme determinant for market introduction of a new production route (see e.g. Cukalovic and Stevens 2008, Chimirri et al. 2010, Cheng et al. 2012, Cao et al. 2013). However, it should be noted that bio 
refineries develop in complex industrial and cultural settings, and their performance interrelates strongly with the character of the larger surrounding technical systems (Sandén and Pettersson 2013). Owing to the above and in line with Singh (2016 p.71), a call for a "broader systems approach to resource management" is necessary. This broader systems analysis, from this perspective, must involve wider system boundaries, from bio-processing alone to entire production and consumption systems, and different research disciplines, from social and natural sciences.

\subsection{Further research needs}

Although advocating a more holistic view by means of a systems perspective, the framework of analysis presented in this study is by no means all-encompassing for answering the question if chemical production can be a viable added pathway for MFW. Examples of further relevant aspects to explore are process design and process economy for a defined production facility. This would include necessary pre-treatment processes, possibilities for co-production with other products, and localization and logistics for feedstock supply. Due to the complex character of MFW fractions, further research is also required to obtain a robust production route for SA. The nutrient composition and the feedstock variance requires attention in relation to process development. Given the local character of feedstock and the amount of water included, it would be of interest to challenge the assumption that a site should be of a certain size to be economically viable and explore whether there are options for small-scale production instead.

To this end, it is important to examine in greater detail development paths in other areas that target the same feedstock to predict any potential conflicts of interest. A further analysis of potential end-product applications and their likelihood to succeed on the market would complement the analyses made. The identification of promising markets is likely of great importance for achieving the alignment necessary to synchronize key actors in the value chain.

This study has focused on evaluating the potential of MFW slurry. Due to the large variance of soluble sugars within a fraction of MFW, the solid fraction of MFW might be more suitable for use as a carbon and energy source for the industrial production of SA. However, in that event, solid MFW must be degraded using hydrolysis to make the nutrients available for E. coli uptake and subsequent growth. This study has only considered the degradation of the carbohydrate fraction. Thus, more research is needed to investigate the potential release of other nutrients. Alternately, these nutrients need to be supplemented to the cultivation medium. Furthermore, to obtain the solid fraction of MFW, fractionation and drying are required. This will require an input of energy.

The sustainability aspect (approaching both environmental, social and economic dimensions) is not addressed in this study but should be included in the decision support for whether or not to go forward with any research and development activities on specific production routes. Certain environmental impacts and the economic viability of bio-based SA production have been explored (e.g. Morales et al. (2016), Lam et al. (2014), Pinazo et al. (2015), Cok et al. (2014), and Patel and al. (2006)). Using sustainability as a normative guideline means that the desirability of producing biobased SA should be explored by analyzing economic, social, and environmental aspects 
in a long-term and global perspective. Sustainability assessments should preferably include both impacts related to the chosen production system along the entire value chain, and aspects of alternate uses of resources in other applications.

\section{Conclusion}

As a feedstock for microbial growth, mixed food waste (MFW) represents intriguing potential for use in a bio-economy. In this study, the prospects for the production of one specific chemical (succinic acid, SA) from MFW in a specific country (Sweden) were examined. The prospect was analyzed by assessing its technical feasibility in the form of feedstock appropriateness and resource availability, as well as societal drivers and barriers.

Even though, from a biotechnical feasibility and resource availability perspective, the production of SA from MFW seems possible, it lacks both sufficient institutional support and sufficient commitment and alignment of actors along the value chain for development in Sweden. Findings indicate that a holistic view, combining and synthesizing analyses from different perspectives and disciplines, is crucial for a nuanced examination of production prospects in contrast to the use of a single analytical perspective.

To ensure the identification of potential barriers and to take advantage of potential drivers when assessing the viability of chemical production and the use of food waste in a future bio-economy, an interdisciplinary systems perspective is recommended that takes into account the entire value chain. Lessons regarding methodology for similar analyses and ways to approach emergent technology ideas in the bio-economy field can be drawn from this study. While not included in this study, it is recommended that such analyses also take into account goals from a sustainability point of view, including environmental, economic, and social sustainability in a global perspective. 


\section{References}

ACS. (2012). "New biorefinery finds treasure in Starbucks' spent coffee grounds and stale bakery goods." Available from www.acs.org/content/acs/en/pressroom/newsreleases/2012/august/new-biorefineryfinds-treasure-in-starbucks-spent-coffee-grounds-and-stale-bakery-goods.html. Retrieved 2016-06-16.

Ahn, J. H., Y. S. Jang and S. Y. Lee (2016). "Production of succinic acid by metabolically engineered microorganisms." Current Opinion in Biotechnology 42: 54-66.

Avfall Sverige (2015). Svensk Avfallshantering 2015.

Avfall Sverige. (2016a). "Allt fler kommuner samlar in allt mer matavfall." Retrieved 2016-07-01, from www.avfallsverige.se/nyhetsarkiv/nyhetsvisning/artikel/insamlingen-av-matavfalloekade-med-oever-50-procent-2010-2015/.

Avfall Sverige. (2016b). "Kommuner i Sverige som samlar in matavfall." Retrieved 2016-06-22, from www.avfallsverige.se/fileadmin/uploads/Rapporter/Biologisk/Matavfallsinsamling_ja n_2016.pdf.

BECOTEPS (2011). The Bioeconomy in 2030: Delivering Sustainable Growth by Addressing the Grand Societal Challenges, White Paper. Available from www.plantetp.org/images/stories/stories/documents_pdf/brochure_web.pdf.

Begum, S., K. Golluri, G. R. Anupoju, S. Ahuja, B. Gandu, K. Kuruti, R. K. Maddala and S. Yerramsetti Venkata (2016). "Cooked and uncooked food waste: A viable feedstock for generation of value added products through biorefinery approach." Chemical Engineering Research and Design 107: 43-51.

Bergek, A., S. Jacobsson, B. Carlsson, S. Lindmark and A. Rickne (2008). "Analyzing the functional dynamics of technological innovation systems: A scheme of analysis." Research Policy 37(3): 407-429.

Betaprocess. (2012). "The value pyramid." Retrieved 2016-06-22, 2016, from www.betaprocess.eu/the-value-pyramid.php.

BioAmber. (2016). "OUR PRODUCTS. ENTER A NEW, GREENER WORLD OF INFINITE POSSIBILITIES." Retrieved 2016-07-01, from www.bioamber.com/bioamber/en/products.

BioBased Economy. (n.d.). "Bioraffinage." Retrieved 2016-06-22, 2016, from www.biobasedeconomy.nl/wat-is-biobased-economy/themas/bioraffinage_v2/.

Bisaillon, M., H. Hellström, J. Andersson, D. Holmström, H. Sköldberg, J. Torén and A. Widerberg (2013). Styrmedel för ökad biogasproduktion (Policy instruments for increased biogas production), SP Sveriges Teniska Forskningsinstitut. WR-64.

Bozell, J. J. and G. R. Petersen (2010). "Technology development for the production of biobased products from biorefinery carbohydrates - The US Department of Energy's "top 10" revisited." Green Chemistry 12(4): 539-554. 
Cao, Y., R. Zhang, C. Sun, T. Cheng, Y. Liu and M. Xian (2013). "Fermentative Succinate Production: An Emerging Technology to Replace the Traditional Petrochemical Processes." BioMed Research International 2013(Article ID 723412).

Cheng, K. K., X. B. Zhao, J. Zeng and J. A. Zhang (2012). "Biotechnological production of succinic acid: Current state and perspectives." Biofuels, Bioproducts and Biorefining 6(3): 302-318.

Chimirri, F., F. Bosco, R. Ceccarelli, A. Venturello and F. Geobaldo (2010). "Succinic acid and its derivatives: Fermentative production using sustainable industrial agrofood by-products and its applications in the food industry." Italian Journal of Food Science 22: 119-125.

Choi, S., C. W. Song, J. H. Shin and S. Y. Lee (2015). "Biorefineries for the production of top building block chemicals and their derivatives." Metabolic Engineering 28: 223239.

Cok, B., I. Tsiropoulos, A. L. Roes and M. K. Patel (2014). "Succinic acid production derived from carbohydrates: An energy and greenhouse gas assessment of a platform chemical toward a bio-based economy." Biofuels, Bioproducts and Biorefining 8(1): 1629.

Cukalovic, A. and C. V. Stevens (2008). "Feasibility of production methods for succinic acid derivatives: A marriage of renewable resources and chemical technology." Biofuels, Bioproducts and Biorefining 2(3): 505-529.

Esteves, S. and D. Devlin. (2010). "Food Waste Chemical Analysis." Retrieved 2016o6-28, from

www.wrapcymru.org.uk/sites/files/wrap/Technical_report_food_waste_characterisati on_Wales_2009x2.9086.pdf.

European Commission (2008a). "Coordinated action to accelerate the development of innovative markets of high value for Europe - the Lead Markets Initiative."

Memo/o8/5.

European Commission (2008b). "DIRECTIVE 2008/98/EC OF THE EUROPEAN PARLIAMENT AND OF THE COUNCIL of 19 November 2008 on waste and repealing certain Directives." Official Journal of the European Union L 312/13.

European Commission (2009). "DIRECTIVE 2009/28/EC OF THE EUROPEAN PARLIAMENT AND OF THE COUNCIL of 23 April 2009 on the promotion of the use of energy from renewable sources and amending and subsequently repealing Directives 2001/77/EC and 2003/30/EC." Official Journal of the European Union.

European Commission (2010). "Being wise with waste: the EU's approach to waste management."

European Commission (2011). "COMMUNICATION FROM THE COMMISSION TO THE EUROPEAN PARLIAMENT, THE COUNCIL, THE EUROPEAN ECONOMIC AND SOCIAL COMMITTEE AND THE COMMITTEE OF THE REGIONS Roadmap to a Resource Efficient Europe." COM/2011/0571 final.

European Commission (2012). COMMUNICATION FROM THE COMMISSION TO THE EUROPEAN PARLIAMENT, THE COUNCIL, THE EUROPEAN ECONOMIC 
AND SOCIAL COMMITTEE AND THE COMMITTEE OF THE REGIONS Innovating for Sustainable Growth: A Bioeconomy for Europe. Brussels, 13.2.2012 COM (2012) 60 final.

European Commission (2014). Where next for the European bioeconomy? The latest thinking from the European Bioeconomy Panel and the Standing Committee on Agricultural Research Strategic Working Group (SCAR).

http://ec.europa.eu/research/bioeconomy/pdf/where-next-for-european-bioeconomyreport-0809102014_en.pdf, Directorate-General for Research and Innovation.

European Commission. (2016a). "15 recommendations for an increased uptake of biobased products in public procurement." Retrieved 2016-07-01, from http://ec.europa.eu/growth/toolsdatabases/newsroom/cf/itemdetail.cfm?item_id=8767.

European Commission. (2016b). "Horizon 2020. Bioeconomy." Retrieved 2016-05-23, from https://ec.europa.eu/programmes/horizon2020/en/h2020-section/bioeconomy.

European Environmental Agency (2013). Municipal waste management in Sweden. From: www.eea.europa.eu/.

Eurostat. (2016). "Share of renewable energy in fuel consumption of transport" Retrieved 2016-06-30, from http://ec.europa.eu/eurostat/tgm/table.do?tab=table\&init=1\&language=en\&pcode=ts dcc340\&plugin $=1$

Formas (2012). Swedish Research and Innovation Strategy for a Bio-based Economy. Report: R3:2012.

Grin, J., J. Rotmans and J. N. Y. L. R. Schot (2010). Transitions to Sustainable Development. New Directions in the Study of Long term transformative change. New York/London, Routledge.

Han, W., D. N. Liu, Y. W. Shi, J. H. Tang, Y. F. Li and N. Q. Ren (2015). "Biohydrogen production from food waste hydrolysate using continuous mixed immobilized sludge reactors." Bioresource technology 180: 54-58.

Hekkert, M., R. A. A. Suurs, S. Negro, S. Kuhlmann and R. Smits (2007). "Functions of innovation systems: a new approach for analysing technological change." Technological Forecasting and Social Change 74: 413-432.

HLPE (2013). Biofuels and food security. A report by the High Level Panel of Experts on Food Security and Nutrition of the Committee on World Food Security. Rome 2013.

Hong, S. H., S. Y. Moon and S. Y. Lee (2003). "Prediction of maximum yields of metabolites and optimal pathways for their production by metabolic flux analysis." Journal of microbiology and biotechnology 13(4): 571-577.

Huang, H., V. Singh and N. Qureshi (2015). "Butanol production from food waste: a novel process for producing sustainable energy and reducing environmental pollution." Biotechnology for Biofuels 8(1).

International Energy Agency (2013). Bio-based chemicals. Value added products from biorefineries. IEA Bioenergy. Task 42 Biorefinery. 
Jansen, M. L. A. and W. M. van Gulik (2014). "Towards large scale fermentative production of succinic acid." Current Opinion in Biotechnology 30: 190-197.

Jantama, K., X. Zhang, J. Moore, K. Shanmugam, S. Svoronos and L. Ingram (2008). "Eliminating side products and increasing succinate yields in engineered strains of Escherichia coli C." Biotechnology and bioengineering 101(5): 881-893.

Kemiföretagen i Stenungsund. (n.d.). "Sustainable Chemistry 2030." Retrieved 201607-01, from www.kemiforetagenistenungsund.se/pdf/foldereng.pdf.

Lam, K. F., C. C. J. Leung, H. M. Lei and C. S. K. Lin (2014). "Economic feasibility of a pilot-scale fermentative succinic acid production from bakery wastes." Food and Bioproducts Processing 92(3): 282-290.

Lane, J. (2015). "The DOE's 12 Top Biobased Molecules - what became of them?" Retrieved 2016-06-29, from www.biofuelsdigest.com/bdigest/2015/04/30/the-does12-top-biobased-molecules-what-became-of-them/.

Leung, C. C. J., A. S. Y. Cheung, A. Y. Z. Zhang, K. F. Lam and C. S. K. Lin (2012). "Utilisation of waste bread for fermentative succinic acid production." Biochemical Engineering Journal 65: 10-15.

Lewis, R. J. (2007). Hawley's Condensed Chemical Dictionary, 15th Edition, Wiley.

Lin, C. S. K., L. A. Pfaltzgraff, L. Herrero-Davila, E. B. Mubofu, S. Abderrahim, J. H. Clark, A. A. Koutinas, N. Kopsahelis, K. Stamatelatou, F. Dickson, S. Thankappan, Z. Mohamed, R. Brocklesby and R. Luque (2013). "Food waste as a valuable resource for the production of chemicals, materials and fuels. Current situation and global perspective." Energy and Environmental Science 6(2): 426-464.

Lin, H., G. N. Bennett and K. Y. San (2005). "Fed-batch culture of a metabolically engineered Escherichia coli strain designed for high-level succinate production and yield under aerobic conditions." Biotechnology and bioengineering 90(6): 775-779.

Liu, J., S. H. Dantoft, A. Würtz, P. R. Jensen and C. Solem (2016). "A novel cell factory for efficient production of ethanol from dairy waste." Biotechnology for Biofuels 9(1).

Markard, J., R. Raven and B. Truffer (2012). "Sustainability transitions: An emerging field of research and its prospects." Research Policy 41(6): 955-967.

Markard, J., M. Stadelmann and B. Truffer (2009). "Prospective analysis of technological innovation systems: Identifying technological and organizational development options for biogas in Switzerland." Research Policy 38 (4): 655-667.

Matsakas, L., D. Kekos, M. Loizidou and P. Christakopoulos (2014). "Utilization of household food waste for the production of ethanol at high dry material content." Biotechnology for biofuels 7(1): 1 .

Miljö- och energidepartementet (1998). "Miljöbalk (1998:808)" Svensk författningssamling 1998:808.

Morales, M., M. Ataman, S. Badr, S. Linster, I. Kourlimpinis, S. Papadokonstatakis, V. Hatzimanikatis and K. Hungerbühler (2016). "Sustainability Assessment of Succinic Acid Production Technologies from Biomass using Metabolic Engineering." Energy \& Environmental Science In press. 
Mossberg, J. (2013). Chemical Industry Companies in Sweden. Vinnova Analysis VA 2013:1.

Nilsson, K. and J. Sundberg (2009). Lagar, direktiv och styrmedel viktiga för avfallssystemets utveckling (Laws, directives and policy instruments important for the development of the waste management system), Waste Refinery.

NNFCC (2013). "Succinic Acid." Platform chemicals - Renewable Chemicals Factsheet.

Nova institute (2015a). Bio-based Building Blocks and Polymers in the World. Capacities, Production and Applications: Status Quo and Trends towards 2020. Nova institute.

NOVA Institute (2015b). Bio-based Building Blocks and Polymers in the World. Capacities, Production and Applications: Status Quo and Trends towards 2020. Available from www.bio-based.eu/market_study/media/files/15-05-13_Biobased_Polymers_and_Building_Blocks_in_the_World-nova_Booklet.pdf.

Patel, M. and E. al. (2006). Medium and Long-term Opportunities and Risks of the Biotechnological Production of Bulk Chemicals from Renewable Resources - The Potential of White Biotechnology The BREW Project, Utrecht University.

Pimentel, D. and M. Burgess (2014). "Biofuel production using food." Environment, Development and Sustainability 16(1): 1-3.

Pinazo, J. M., M. E. Domine, V. Parvulescu and F. Petru (2015). "Sustainability metrics for succinic acid production: A comparison between biomass-based and petrochemical routes." Catalysis Today 239: 17-24.

Pleissner, D., W. C. Lam, Z. Sun and C. S. K. Lin (2013). "Food waste as nutrient source in heterotrophic microalgae cultivation." Bioresource technology 137: 139-146.

Regeringskansliet (2008). En sammanhållen klimat- och energipolitik. Regeringens proposition 2008/o9:162.

Rosander, E., M. Svedendahl Humble and A. Veide (2016). "Municipal solid waste as carbon and enerfy source for Escherichia coli " Submitted to Avanced in Waste Management and Recycling

Sahlin, J., D. Holmström and M. Bisaillon (2013). Import av avfall till energiutvinning i Sverige, Waste Refiniery.

Sakai, K., M. Taniguchi, S. Miura, H. Ohara, T. Matsumoto and Y. Shirai (2004). "Making plastics from garbage: A novel process for poly-L-lactate production from municipal food waste." Journal of Industrial Ecology 7(3-4): 63-74.

Sanchez-Vazquez, S. A., H. C. Hailes and J. R. G. Evans (2013). "Hydrophobic polymers from food waste: Resources and synthesis." Polymer Reviews 53(4): 627-694.

Sánchez, A. M., G. N. Bennett and K.-Y. San (2005). "Novel pathway engineering design of the anaerobic central metabolic pathway in Escherichia coli to increase succinate yield and productivity." Metabolic engineering 7(3): 229-239.

Sandén, B. and K. Pettersson (2013). Systems Perspectives on Biorefineries. 
SAT-BBE (2016). Design of a system analysis tools framework for the EU bio-based economy strategy. www3.lei.wur.nl/satbbe/default.aspx.

Scarlat, N., J. F. Dallemand, F. Monforti-Ferrario and V. Nita (2015). "The role of biomass and bioenergy in a future bioeconomy: Policies and facts." Environmental Development 15: 3-34.

SFS (2005). "Lag (2005:1248) om skyldighet att tillhandahålla förnybara drivmedel." SFS 2005:1248.

Sheldon, R. A. (2014). "Green and sustainanable manufacture of chemicals from biomass: state of the art." Green Chemistry 2014(16): 950.

Singh, J. (2016). Beyond Waste Management. Doctoral Thesis, KTH Royal Institute of Technology.

SIS (2016). Growing bio-economy spawns new standards. Press release Swedish Standards Institute 2016-03-03.

Song, H. and S. Y. Lee (2006). "Production of succinic acid by bacterial fermentation." Enzyme and microbial technology 39(3): 352-361.

SOU (2013). "Fossilfrihet på väg Betänkande av Utredningen om fossilfri fordonstrafik." SOU 2013:84.

Stockholms Tingsrätt (2002). "DOM 2002-03-14 meddelad i Stockholm, Mål nr M 548-99."

Sun, Z., M. Li, Q. Qi, C. Gao and C. S. K. Lin (2014). "Mixed Food Waste as Renewable Feedstock in Succinic Acid Fermentation." Applied Biochemistry and Biotechnology 174(5): 1822-1833.

Swedish Energy Agency (2014). "Teknologiska innovationssystem inom energiområdet. En praktisk vägledning till identifiering av systemsvagheter som motiverar särskila politiska åtaganden." ER 2014:23.

Swedish Energy Agency (2015). Energiläget 2015. Eskilstuna ET2015:08.

Swedish Environmental Protection Agency (2012). "Från avfallshantering till resurshushållning Sveriges avfallsplan 2012-2017." Naturvårdsverket Rapport 6502.

Swedish Environmental Protection Agency (2013). Matavfallsmängder i Sverige. ISBN 978-91-620-8694-7.

Swedish Environmental Protection Agency (2014). "Etappmålen - Naturvårdsverket."

Swedish Environmental Protection Agency (2015). "Tillsammans vinner vi på ett giftfritt och resurseffektivt samhälle. Sveriges program för att förebygga avfall 20142017." Naturvårdsverket Rapport 6654. ISBN 978-91-620-6654-3.

Swedish Environmental Protection Agency. (2016, 2016-06-10). "Avfallsförbränning Vägledning om bestämmelser för förbränningsanläggningar där avfall förbränns."

Retrieved 2016-06-29, 2016, from www.naturvardsverket.se/Stod-imiljoarbetet/Vagledningar/Industri-och-forbranning/Avfallsforbranning/. 
Swedish National Food Agency, Swedish Environmental Protection Agency and Swedish Board of Agriculture (n.d.). "Låt matavfall bli smart avfall."

Svensk författningssamling (2001). "Förordning (2001:512) om deponering av avfall " SFS 2001:512.

Svensk författningssamling (2011). "Avfallsförordning." SFS 2011:927.

To, H. and R. Q. Grafton (2015). "Oil prices, biofuels production and food security: past trends and future challenges." Food Security 7(2): 323-336.

Ulmanen, J. H. (2013). Exploring policy protection in biofuel niche development. A policy and Strategic Niche Management analysis of Dutch and Swedish biofuel development, 1970-2010.

US Department of Energy (2004). Top Value Added Chemicals from Biomass Volume I-Results of Screening for Potential Candidates from Sugars and Synthesis Gas. US Department of Energy.

Wageningen UR. (2016). "Spin-off: From organic waste to valuable chemical building blocks." Retrieved 16.06, 2016, from www.wageningenur.nl/en/newsarticle/Spin-offFrom-organic-waste-to-valuable-chemical-building-blocks.htm.

Wang, Q., H. Ma, W. Xu, L. Gong, W. Zhang and D. Zou (2008). "Ethanol production from kitchen garbage using response surface methodology." Biochemical Engineering Journal 39(3): 604-610.

Weber, K. M. and H. Rohracher (2012). "Legitimizing research, technology and innovation policies for transformative change: Combining insights from innovation systems and multi-level perspective in a comprehensive 'failures' framework." Research Policy 41(6): 1037-1047.

Vemuri, G., M. Eiteman and E. Altman (2002). "Succinate production in dual-phase Escherichia coli fermentations depends on the time of transition from aerobic to anaerobic conditions." Journal of Industrial Microbiology and Biotechnology 28(6): 325-332.

Vänersborgs Tingsrätt (2015). "DOM 2015-12-10 meddelad i Vänersborg, Mål nr M 4008-14."

Yan, S., J. Li, X. Chen, J. Wu, P. Wang, J. Ye and J. Yao (2011). "Enzymatical hydrolysis of food waste and ethanol production from the hydrolysate." Renewable Energy 36(4): 1259-1265.

Zhang, A. Y. Z., Z. Sun, C. C. J. Leung, W. Han, K. Y. Lau, M. Li and C. S. K. Lin (2013). "Valorisation of bakery waste for succinic acid production." Green Chemistry 15(3): 690-695. 
Through our international collaboration programmes with academia, industry, and the public sector, we ensure the competitiveness of the Swedish business community on an international level and contribute to a sustainable society. Our 2,200 employees support and promote all manner of innovative processes, and our roughly 100 testbeds and demonstration facilities are instrumental in developing the future-proofing of products, technologies, and services. RISE Research Institutes of Sweden is fully owned by the Swedish state.

I internationell samverkan med akademi, näringsliv och offentlig sektor bidrar vi till ett konkurrenskraftigt näringsliv och ett hållbart samhälle. RISE 2200 medarbetare driver och stöder alla typer av innovationsprocesser. Vi erbjuder ett 100-tal test- och demonstrationsmiljöer för framtidssäkra produkter, tekniker och tjänster. RISE Research Institutes of Sweden ägs av svenska staten.

RISE Research Institutes of Sweden AB

Box 24036, SE-400 22 GÖTEBORG, Sweden

Telephone: +46 105165000

E-mail: info@ri.se, Internet: www.ri.se
Energy and circular economy

RISE Report 2018:30

ISBN: 